\title{
Funding Strategy Bali-Mandara Toll Road Rest Area Investment Plan
}

\author{
Erwin Rasyid $^{1}$, Sri Saraswati ${ }^{2}$ \\ ${ }^{1}$ STIE Unisadhuguna and Universitas Budi Luhur, Jakarta, Indonesia \\ ${ }^{2}$ STIE Unisadhuguna, Jakarta, Indonesia
}

Email address:

erwin.rasjid@ubs-usg.ac.id (E. Rasyid), atiekwibowo@gmail.com (S. Saraswati)

\section{To cite this article:}

Erwin Rasyid, Sri Saraswati. Funding Strategy Bali-Mandara Toll Road Rest Area Investment Plan. Science Journal of Business and Management. Vol. 7, No. 3, 2019, pp. 59-66. doi: 10.11648/j.sjbm.20190703.11

Received: May 22, 2019; Accepted: July 17, 2019; Published: August 5, 2019

\begin{abstract}
Construction of toll roads in Bali by PT. Jasamarga Bali Tol (JBT) as by PT. JBT has to pay the loans used for due to the loans of building the road. Even, though PT. JBT's income is increasing, it has not been able to cover the obligations of the company to pay the loan. Then, PT. JBT considers making a rest area as a business unit to multiply their income. An effective analysis of investment will provide financial solutions for PT. JBT. This study aims at identifying the best funding pattern that can be implemented for the rest area investment plan. This research focuses on three funding patterns, namely the pattern of loans/debts, own costs, and Build-Operate-Transfer. After the results of the study, the following results were obtained: In the room rental pattern + business concession, there was a 7 year 9 month payback period, internal rate of return $9.52 \%($ IRR $<13 \%)$, and net present value of $-\mathrm{Rp} 75.72$ billion in $\mathrm{I}=13 \%$ and a period of 10 years $(\mathrm{NPV}<0)$. Meanwhile, the revenue-sharing pattern obtained a 6-year 8-month payback period, internal rate of return $13.55 \%$ (IRR $>13 \%$ ), and the net present value of Rp. 12.93 billion (NPV >0). Lastly, the loan pattern is not feasible because the NPV project is smaller than 0 (zero) and IRR $<13 \%$. The cost pattern is not feasible because it takes a long time to raise funds and the BOT pattern is possible because the NPV value is greater than 0 (zero) and IRR $>13 \%$.
\end{abstract}

Keywords: Funding Pattern, Business Feasibility Analysis, Capital Budgeting

\section{Introduction}

PT. JASAMARGA BALI TOL (JBT) is the regulator of the Toll Road. With its services, the company managed to obtain Rp. 122 billion in 2015 and Rp. 142 billion in 2016. Although the annual income increased, they still have not reached the target to pay installments and bank interest with the amount of Rp. 160 billion. [8]

Therefore, the party from PT. JASAMARGA BALI TOL (JBT) took some actions to cover the deficit. One effort that can be done is to build a rest area that has the potential to increase the number of toll road users and the revenue. "We have to cover the deficit by looking for other sources of income and that is legitimate." [8]

\section{Literature Review}

Project funding is an effort to obtain funds or capital used to finance a project which generally includes the following activities: [11]

a. assessing the source of funds;

b. developing an best funding structure;

c. analyzing interest rates on investment decisions;

d. negotiating with prospective funders

\subsection{Sources and Types of Project Funding}

Basically, there are various kinds of funding sources for a company, which are categorized as equity and debt. [1]

A. Equity

1. Issue shares Sales of newly issued shares will be funds that can be used to finance the project. The stock market price is determined by the economic performance of the company. By buying shares, new investors will become stakeholders of the company, which means that the stockholders also have the company's equity [5].

2. Retained Earnings Project funds can come from retained earnings of the company. This event means that funds are obtained from within the organization itself. 
Usually, this event is an important source for project funding [6].

B. Debt

Debt is a sum (principal loan) borrowed in a certain period to fund the project. Therefore, creditors will charge interest at a fixed percentage and repay the principal by the terms of the agreement [3]. Often, creditors need collateral for loaned funds. The general agreement terms include:

1. Arrangement and schedule of returns;

2. Security for the lender;

3. Fee and administration, fees;

4. Interest on loans.

Loans or debts are considered not affected by inflation, because once the interest and principal installments are determined by the schedule and the magnitude, generally the impact of inflation is not considered anymore [10].

The arrangement and schedule of debt repayments in the project are:

1. Decreased Installments: the number of fixed installments with interest calculated from the remaining principal. The amount of installments decreases over time.

2. Maturity returns: the principal loan repaid at maturity, that is, at the end of the loan.

3. Grace Period: the grace period for installments given by the principal.

This structure is suitable for projects that do not produce production at all until a certain time. After generating cash flow, the debtor starts paying back the loan.

C. Build Operate Transfer (BOT)

In the BOT funding pattern, the term Full Limited or NonRecourse Financing is also known to the sponsor party. Full recourse financing occurs when the sponsor is responsible for repaying the debt from the project following the agreed loan rules. For short recourse, full financing is not required from the sponsor. Usually, in limited recourse, financing loans are carried out for specific matters only, and/or half the obligations is left to third parties. For Non-Recourse financing, the lender only relies on cash flow and current and future income from a economic unit to repay the debt. Usually, for limited and non-recourse financing, guarantees are needed as assets from the economic unit (project) [15].

The BOT pattern is widely used to finance large infrastructure projects where the government or a StateOwned Enterprise (BUMN) wants to rely on companies that are experienced in building and operating a school that will eventually be transferred to the government or BUMN [14].

The following is illustrating the BOT funding pattern with a limited resource structure.

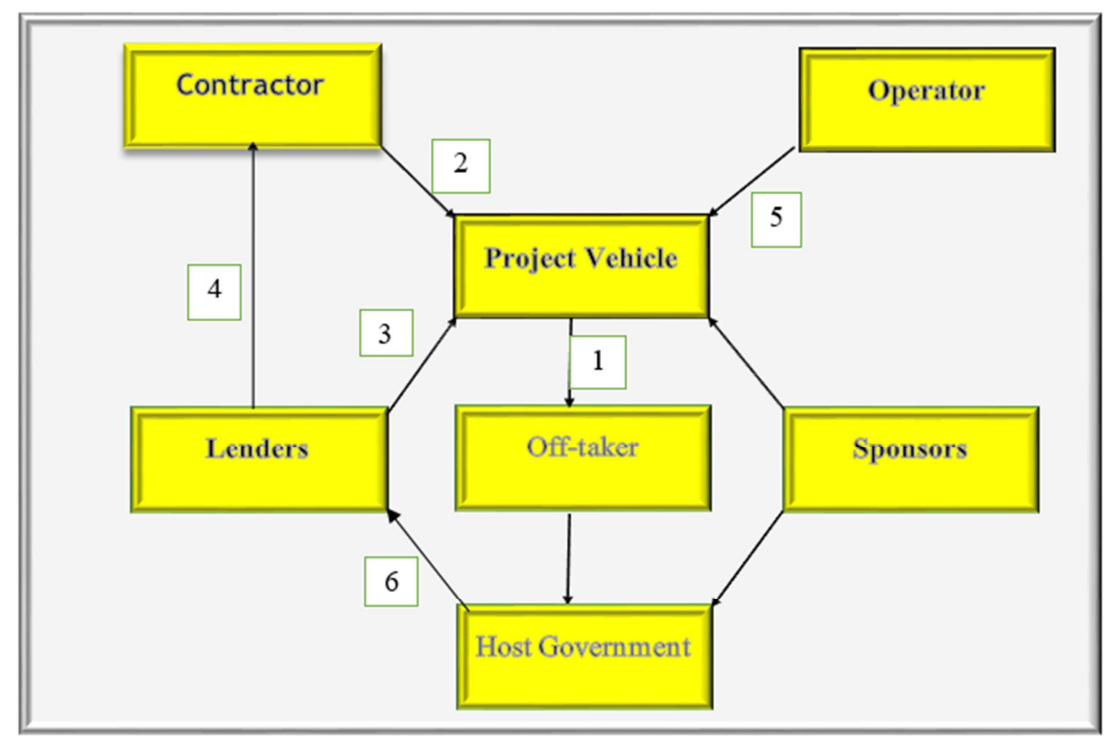

Figure 1. BOT Pattern with Limited Resources Structure.

The steps of the BOT pattern above can be explained as follows:

1. Project vehicle signs a long-term sale-purchase agreement. This event makes a guarantee for the project that the product will get buyers for a certain period sometime. Project vehicle contracts with Engineering, Procurement and Construction (EPC) with contractors who will carry out construction of the project.

2. Project vehicle makes a credit/loan agreement with the borrower, bank or financial institution. In making this loan agreement, a Sales Purchase Agreement is also included with the offtaker so that it may show the estimated cash flow that can be generated by the project.

3. Loans given by the lender will be used to finance the construction of the project.

4. Project vehicle binds a contract with an operator company that will carry out Operation \& Maintenance $(\mathrm{O} \& \mathrm{M})$ of this project in exchange for long-term $\mathrm{O} \&$ $\mathrm{M}$ fees generated from project revenue. $\mathrm{O} \& \mathrm{M}$ can actually be done by the relevant parties, namely the sponsor and project owner. However, this should be 
discussed further and there should be a special agreement. As the guarantor of the offtake obligation stipulated in the Sales and Purchase Agreement with the project vehicle, the government has limited liability shares in this BOT scheme.

\subsection{Capital Budgeting}

Financial analysis to assess the feasibility of an investment project is a method that is done by comparing the costs that must be incurred with the revenue expected to be received from the investment project [2]. For investments that are projected to obtain sustainable income for a certain period, the calculation is done discounted cash flow. Some criteria in capital budgeting that can be used to evaluate long-term investments are Payback Period, Net Present Value and Internal Rate of Return [3].

\section{A. Payback Period}

A payback period of an investment describes time needed to recover funds that have been invested in a project. Period is the time that the company takes from the very beginning of the fund's investment until the cumulative net cash flow reaches the same time as the initial investment made [11].

This payback period method is widely used because the calculations are easy to do and simple. Measurements with the payback period method are for consideration of company liquidity. The shorter, an investment, the smaller the uncertainty risk that will be caused. To wit, it can be said that the shorter the period of return on investment produced by a project, the more feasible for the project to be realized.

However, this method has several disadvantages. First, the payback period method does not allow for the time value of money concept. This method also ignores cash flows received after the return period or after the payback period is reached, so that this criterion is more a some of the speed of return of funds and not a measure of profitability. Calculations with this method cannot provide a clear picture whether investment can increase the value of the company or not.

The payback period formula is:

If the cash flow per year has the same amount.

$$
\text { Payback period }=\frac{\text { total investment }}{\text { annual cashflow }} \times 1 \text { year }
$$

Formula 1: Payback Period with Same Cash Flow

If the cash flow is different, then it must be searched one by one by reducing the total investment with the cash flow until the total investment results are the same as the cash flow in a particular year.

$$
\text { Payback period }=n+\frac{a-b}{c-b} \times 1 \text { year }
$$

\section{Formula 2: Payback Period with Different Cash Flow} Where:

$\mathrm{n}=$ last year when the amount of cash flow still cannot cover the original investment

$\mathrm{a}=$ total original investment $\mathrm{b}=$ the cumulative amount of cash flow in year $\mathrm{n}$

$\mathrm{c}=$ the cumulative amount of cash flow in the year to $\mathrm{n}+\mathrm{L}$

B. Net Present Value

Net Present Value is a method most commonly used by companies for evaluating the feasibility of a project [6]. This method is used to overcome shortcomings in the payback period method since this method calculates the time value of money. In this method, the current monetary value is first calculated from the expected cumulative cash inflows in the future, and the present money value of cash outflows because of the cost of capital of the project or discount rate desired.

The difference between here value of the cash inflows estimated to be derived from investments invested and the investment value spent to finance the project is called the Net Present Value (NPV). If the Net Present Value is positive, then the investment proposal can be accepted. This event means that the investment to be made can increase the value of the company. Whereas, if the Net Present Value obtained is negative, then the investment proposal for the project is rejected, or it can reduce the value of the company. Meanwhile, if the Net Present Value results are zero, then it can be interpreted that the investment to be made will not change the value of the company. The company can accept or reject the investment proposal.

The Net Present Value formula is as follows:

$$
\text { Net Present Value }=\sum_{t}^{N} \frac{C F_{t}}{(1+K)^{t}}-I O
$$

\section{Formula 3: Net Present Value}

Where:

$\mathrm{NPV}=$ Present value of investment

$\mathrm{CFt}=$ Annual cash flow generated by the project

$\mathrm{k}=$ required rate of return

$\mathrm{N}=$ investment project age

IO = Initial Outlay / capital issued

Besides taking into account the time value of money, other advantages of the Net Present Value method include:

1. Considering all existing inflows;

2. Considering the risks of future inflows for return on investment capital;

3. Through calculations using the NPV method, it can be clearly seen whether the investment can increase the value of the company or not;

4. The shortcomings of the NPV method besides having to determine earlier the required rate of return or the calculation of the cost of capital; the results of this method are reflected in the value of the currency invested not in percentage.

C. Internal Rate of Return (IRR)

This is the discount rate or the cost of capital that will equate the sum of the present values of a project to zero. It is the rate of discount in which discounted cash inflows and outflows of a project are balanced. In other words, internal rate of returns is the maximum rate of interest a firm can afford to pay if a project is financed with borrowed funds and the project cash inflows are to be used to liquidate the loan. It is equally the minimum rate of interest a lender is willing to 
accept for releasing fund to the borrower. Conventionally, if the internal rate of returns exceeds the prevailing rate (i.e. external rate of return or cost of capital), the project is considered viable. The internal rate of return is defined as:

$$
I O=\sum_{t=1}^{N} \frac{C F_{t}}{(1+I R R)^{t}}
$$

Formula 4: Internal Rate of Return (IRR)

Where:

$\mathrm{NPV}=0$

$\mathrm{CFt}=$ Annual cash flow generated by the project

$\mathrm{IRR}=$ Discount rate

$\mathrm{N}=$ investment project age

$\mathrm{IO}=$ Initial Outlay / capital issued

If the calculation of Internal Rate of Return is greater than the cost of capital, then the resulting return is greater than expected. With this greater return, investment project proposals should be accepted. Conversely, if the Internal Rate of Return is smaller than the cost of capital, it is estimated that the return generated from the proposed investment is smaller than expected. If the return expected to be generated from the investment is the same as the company expected, the calculation of Internal Rate of Return will be the same as the cost of capital.

\section{Research Method}

This qualitative study is descriptive research. Descriptive research is the type of research that aims to describe certain social phenomena including the relationship of activities, attitudes, views, and ongoing processes and the influence of a phenomenon in detail. Descriptive research is intended to describe the problems in research [18].

The research data were secondary data obtained from literature, books, and scientific works that are related to the problems addressed. The main purpose of this literature study is to get theoretical concepts that regard the research problems.

\section{Results and Discussion}

The rest area built or studied is a rest area on one side of the toll road. Projection of vehicles through toll roads refers to projections made in the existing toll road Business Plans. The projected number of vehicles through one side of the toll road is assumed to be $50 \%$ of the projected number of vehicles via the toll road that has been mentioned.

The assumed compositions of Group 1 vehicle are as follows:

a. Sedan / Jeep vehicles: $70 \%$ of the total Group 1 vehicles, with an average passenger of 4 (four) per vehicle.

b. Pick up vehicles: $10 \%$, with an average number of passengers 2 (two) passengers per vehicle.

c. Bus Vehicles: $20 \%$, with an average passenger number of 20 people per vehicle.

While the assumed number of rest area visitors are as follows:

a. $5 \%$ of toll road users

b. $25 \%$ of domestic tourists visiting Bandung Regency

c. $1 \%$ of the population / local community

The form of cooperation between the JBT and the tenants / managers studied is:

The form of cooperation between JBT and the Partners is Build, use, deliver or build, operate and Transfer (BOT). JBT as Toll Road Business Entity (BUJT) Bali Mandara, Toll Road Concession Holders will hand over the construction of facilities and infrastructure area to selected Partners. Partners will finance all Rest Area facilities and infrastructure. In a certain period, the chosen partner will be given the Concession Right to manage the Rest Area Facilities and Infrastructure by providing profit sharing to JBT.

JBT also has the right to employ some facilities and infrastructure built and funded by selected partners, and to run other businesses, including advertisements. After the concession period has ended, all the rest area facilities and infrastructure are submitted by the selected Partner to JBT. The pattern of cooperation for PT. Jasamarga Bali Tol is divided into two alternatives, namely:

a. Rent Rooms and Concessions

Rent a room that is calculated from the area and room rental rates. Business concessions, which are calculated from the results of sales (gross turnover) achieved. Room rental, rates are assumed to be Rp. 300,000 per M2 / month with a $15 \%$ increase every two years, and a business concession of $7 \%$ is calculated from the sales (gross turnover) achieved.

b. Revenue Sharing Patterns

JBT receives a share of sales proceeds, assuming JBT gets $30 \%$ and managers $70 \%$ of total sales revenue achieved.

\subsection{Source of Project Funding}

Basically, there are various kinds of potential funding sources for a company, which are categorized as equity and debt.

\subsection{Collaboration by Renting Locations and Business Concessions}

In this cooperation, the income of PT. JBT is obtained from:

1. Room rent that is calculated from the room area and room rental rates;

2. Business concessions which are calculated from sales (gross turnover) achieved.

Room rental rates are assumed to be Rp. 300,000 per ${ }^{\mathrm{M} 2} /$ month with a $15 \%$ increase every two years, and a business concession of $7 \%$ is calculated from the total sales (gross turnover) achieved.

Costs that are borne by JBT include:

a. Environmental maintenance costs, which are assumed to be $3 \%$ of total revenue;

b. $1 \%$ general fee calculated from total revenue;

c. Depreciation costs that include:

1. $5 \%$ building (assuming a 20 year economic life)

2. Grounding parking and road environment and other 
facilities $10 \%$ (assuming a 10 year economic life).

Based on the explanation above, the profit and loss

projection for the TPW Project with the income from rooms rental and business concessions is as follows:

Table 1. Profit / Loss Projection Pattern for Rent of Room / Business Concession.

\begin{tabular}{|c|c|c|c|c|c|c|c|c|c|c|c|}
\hline Profit / Loss Projection & 2016 & 2017 & 2018 & 2019 & 2020 & 2021 & 2022 & 2023 & 2024 & 2025 & 2026 \\
\hline JBT & $\mathbf{0}$ & 1 & 2 & 3 & 4 & 5 & 6 & 7 & 8 & 9 & 10 \\
\hline $\begin{array}{l}\text { Total Revenue } \\
\text { Operational Cost: }\end{array}$ & 0,00 & 53,50 & 57,49 & 68,77 & 74,66 & 85,73 & 89,87 & 103,19 & 108,62 & 124,70 & 131,83 \\
\hline -Employee Cost & 0,00 & 1,07 & 1,15 & 1,38 & 1,49 & 1,71 & 1,80 & 2,06 & 2,17 & 2,49 & 2,63 \\
\hline -Maitenance Cost & 0,00 & 2,67 & 2,87 & 3,44 & 3,73 & 4,29 & 4,49 & 5,16 & 5,43 & 6,24 & 6,59 \\
\hline -General Fees & 0,00 & 0,53 & 0,57 & 0,69 & 0,75 & 0,86 & 0,90 & 1,03 & 1,09 & 1,25 & 1,32 \\
\hline Operational Cost & 0,00 & 4,27 & 4,59 & 5,51 & 5,97 & 6,86 & 7,19 & 8,25 & 8,69 & 9,98 & 10,54 \\
\hline Total Cost & 0,00 & 44,67 & 44,99 & 45,91 & 46,37 & 47,26 & 47,59 & 48,65 & 49,09 & 50,38 & 50,94 \\
\hline EBIT & 0,00 & 8,83 & 12,50 & 22,86 & 28,29 & 38,47 & 42,28 & 54,54 & 59,53 & 74,32 & 80,89 \\
\hline Tax & 0,00 & 2,20 & 3,12 & 5,72 & 7,07 & 9,62 & 10,57 & 13,63 & 14,88 & 18,58 & 20,22 \\
\hline EAT & 0,00 & 6,63 & 9,38 & 17,14 & 21,22 & 28,85 & 31,71 & 40,91 & 44,65 & 55,74 & 60,67 \\
\hline
\end{tabular}

While the cash flow projection is as follows:

Table 2. Projection of Cash Flow Patterns for Room Leases / Business Concessions.

\begin{tabular}{|c|c|c|c|c|c|c|c|c|c|c|c|}
\hline Projection of Cash Flow & 2016 & 2017 & 2018 & 2019 & 2020 & 2021 & 2022 & 2023 & 2024 & 2025 & 2026 \\
\hline JBT & $\mathbf{0}$ & 1 & 2 & 3 & 4 & 5 & 6 & 7 & 8 & 9 & 10 \\
\hline EBIT & 0,00 & 8,82 & 12,49 & 22,87 & 28,28 & 38,47 & 42,28 & 54,53 & 59,53 & 74,33 & 80,89 \\
\hline Depreciation & 0,00 & 40,40 & 40,40 & 40,40 & 40,40 & 40,40 & 40,40 & 40,40 & 40,40 & 40,40 & 40,40 \\
\hline Tax & 0,00 & 2,21 & 3,12 & 5,72 & 7,07 & 9,62 & 10,57 & 13,63 & 14,88 & 18,58 & 20,22 \\
\hline Operating Cash Flow & 0,00 & 47,01 & 49,77 & 57,55 & 61,61 & 69,25 & 72,11 & 81,30 & 85,05 & 96,15 & 101,07 \\
\hline Investment/Reinvestment & $-500,00$ & 0,00 & 0,00 & 0,00 & 0,00 & 0,00 & 0,00 & 0,00 & 0,00 & 0,00 & 0,00 \\
\hline Salvage Value & 0,00 & 0,00 & 0,00 & 0,00 & 0,00 & 0,00 & 0,00 & 0,00 & 0,00 & 0,00 & 188,85 \\
\hline
\end{tabular}

Based on data from the table above to test the feasibility of the project financially, NPV $=-\mathrm{Rp}$ is obtained. 75.72 billion at $\mathrm{i}$ $=13 \%$ and a period of 10 years. The IRR is $9.52 \%$ and Payback Period is for 7 years 9 months. From these indicators, if the room rental and business concessions are used, this investment is not feasible (NPV Indicator $<0 \&$ IRR $<13 \%$ )

When the Revenue Sharing pattern is used, the TPW Project Profit / Loss Projection looks like this:

Table 3. Pattern of Revenue Sharing.

\begin{tabular}{|c|c|c|c|c|c|c|c|c|c|c|c|}
\hline Profit / Loss Projection & 2016 & 2017 & 2018 & 2019 & 2020 & 2021 & 2022 & 2023 & 2024 & 2025 & 2026 \\
\hline JBT & $\mathbf{0}$ & 1 & 2 & 3 & 4 & 5 & 6 & 7 & 8 & 9 & 10 \\
\hline $\begin{array}{l}\text { Total Revenue } \\
\text { Operational Cost: }\end{array}$ & 0,00 & 61,77 & 71,45 & 81,81 & 93,66 & 107,24 & 122,78 & 140,58 & 160,96 & 184,30 & 211,03 \\
\hline - Employee Cost & 0,00 & 1,24 & 1,43 & 1,64 & 1,87 & 2,14 & 2,46 & 2,81 & 3,22 & 3,69 & 4,22 \\
\hline - Maitenance Cost & 0,00 & 3,09 & 3,57 & 4,09 & 4,68 & 5,36 & 6,14 & 7,03 & 8,05 & 9,22 & 10,55 \\
\hline - General Fees & 0,00 & 0,62 & 0,71 & 0,82 & 0,94 & 1,07 & 1,23 & 1,41 & 1,61 & 1,84 & 2,11 \\
\hline Operational Cost & 0,00 & 4,95 & 5,71 & 6,55 & 7,49 & 8,57 & 9,83 & 11,25 & 12,88 & 14,75 & 16,88 \\
\hline Total Cost & 0,00 & 45,35 & 46,11 & 46,95 & 47,89 & 48,97 & 50,23 & 51,65 & 53,28 & 55,15 & 57,28 \\
\hline EBIT & 0,00 & 16,42 & 25,34 & 34,86 & 45,77 & 58,27 & 72,55 & 88,93 & 107,68 & 129,15 & 153,75 \\
\hline Tax & 0,00 & 4,11 & 6,33 & 8,72 & 11,44 & 14,56 & 18,44 & 22,23 & 26,92 & 32,29 & 38,44 \\
\hline EAT & 0,00 & 12,31 & 19,01 & 26,14 & 34,33 & 43,71 & 54,11 & 66,70 & 80,76 & 96,86 & 115,31 \\
\hline
\end{tabular}

Cash flow projection:

Table 4. Projection of Revenue Sharing.

\begin{tabular}{|c|c|c|c|c|c|c|c|c|c|c|c|}
\hline Projection of Cash Flow & 2016 & 2017 & 2018 & 2019 & 2020 & 2021 & 2022 & 2023 & 2024 & 2025 & 2026 \\
\hline JBT & $\mathbf{0}$ & 1 & 2 & 3 & 4 & 5 & 6 & 7 & 8 & 9 & 10 \\
\hline EBIT & 0,00 & 16,43 & 25,34 & 34,86 & 45,77 & 58,26 & 72,56 & 88,93 & 107,69 & 129,16 & 153,75 \\
\hline Depreciation & 0,00 & 40,40 & 40,40 & 40,40 & 40,40 & 40,40 & 40,40 & 40,40 & 40,40 & 40,40 & 40,40 \\
\hline Tax & 0,00 & 4,11 & 6,33 & 8,72 & 11,44 & 14,56 & 18,14 & 22,23 & 26,92 & 32,29 & 38,44 \\
\hline Operating Cash Flow & 0,00 & 52,72 & 59,41 & 66,54 & 74,73 & 84,10 & 94,82 & 107,10 & 121,17 & 137,27 & 155,71 \\
\hline Investment/Reinvestment & $-500,00$ & 0,00 & 0,00 & 0,00 & 0,00 & 0,00 & 0,00 & 0,00 & 0,00 & 0,00 & 0,00 \\
\hline Salvage Value & 0,00 & 0,00 & 0,00 & 0,00 & 0,00 & 0,00 & 0,00 & 0,00 & 0,00 & 0,00 & 188,85 \\
\hline Net Cash Flow & $-500,00$ & 52,72 & 59,41 & 66,54 & 74,73 & 84,10 & 94,82 & 107,10 & 121,17 & 137,27 & 344,56 \\
\hline
\end{tabular}

Based on data from the table above to test the feasibility of the project financially, the results of NPV $=$ Rp. 12.93 billion at $\mathrm{i}$ 
$=13 \%$ and a period of 10 years. The IRR is $13.55 \%$ and Payback Period is for 6 years 8 months. From these indicators, if a profit sharing scheme is used, this investment is feasible (Indicator NPV $<0 \&$ IRR $<13 \%$ ).

When using the "Debt" funding pattern, the Profit / Loss Projections of the TPW Project with the pattern of Room Leases and Business Concessions are follows:

Table 5. Profit / Loss Patterns of Debt Funding / Debt and Business Concessions.

\begin{tabular}{|c|c|c|c|c|c|c|c|c|c|c|c|}
\hline Profit / Loss Projection & 2016 & 2017 & 2018 & 2019 & 2020 & 2021 & 2022 & 2023 & 2024 & 2025 & 2026 \\
\hline JBT & $\mathbf{0}$ & 1 & 2 & 3 & 4 & 5 & 6 & 7 & 8 & 9 & 10 \\
\hline $\begin{array}{l}\text { Total Revenue } \\
\text { Operational Cost: }\end{array}$ & 0 & 53,5 & 57,49 & 68,77 & 74,66 & 85,73 & 89,87 & 103,19 & 108,62 & 124,7 & 131,83 \\
\hline -Employee Cost & 0,00 & 1,07 & 1,15 & 1,38 & 1,49 & 1,71 & 1,80 & 2,06 & 2,17 & 2,49 & 2,64 \\
\hline -Maitenance Cost & 0,00 & 2,67 & 2,87 & 3,44 & 3,73 & 4,29 & 4,49 & 5,16 & 5,43 & 6,24 & 6,59 \\
\hline -General Fees & 0,00 & 0,53 & 0,57 & 0,69 & 0,75 & 0,86 & 0,90 & 1,03 & 1,09 & 1,25 & 1,32 \\
\hline Operational Cost & 0,00 & 4,27 & 4,59 & 5,51 & 5,97 & 6,86 & 7,19 & 8,25 & 8,69 & 9,98 & 10,55 \\
\hline Depreciation & 0,00 & 40,40 & 40,40 & 40,40 & 40,40 & 40,40 & 40,40 & 40,40 & 40,40 & 40,40 & 40,40 \\
\hline Total Cost & 0,00 & 94,67 & 94,99 & 95,91 & 96,37 & 97,26 & 97,59 & 98,65 & 99,09 & 100,38 & 100,95 \\
\hline EBIT & 0,00 & $-41,17$ & $-37,50$ & $-27,14$ & $-21,71$ & $-11,53$ & $-7,72$ & 4,54 & 9,53 & 24,32 & 30,88 \\
\hline Interest & 0,00 & 50,00 & 45,00 & 40,00 & 35,00 & 30,00 & 25,00 & 20,00 & 15,00 & 10,00 & 5,00 \\
\hline EAI & 0,00 & $-91,17$ & $-82,50$ & $-67,14$ & $-56,71$ & $-41,53$ & $-32,72$ & $-15,46$ & $-5,47$ & 14,32 & 25,88 \\
\hline Tax & 0,00 & 0,00 & 0,00 & 0,00 & 0,00 & 0,00 & 0,00 & 1,14 & 2,38 & 6,08 & 7,72 \\
\hline EAT & 0,00 & $-91,17$ & $-82,50$ & $-67,14$ & $-56,71$ & $-41,53$ & $-32,72$ & $-16,60$ & $-7,85$ & 8,24 & 18,16 \\
\hline
\end{tabular}

Cash flow projection follow:

Table 6. Projection of Cash Flow Patterns of Debt / Debt Funding and Business Concessions.

\begin{tabular}{|c|c|c|c|c|c|c|c|c|c|c|c|}
\hline Projection of Cash Flow & 2016 & 2017 & 2018 & 2019 & 2020 & 2021 & 2022 & 2023 & 2024 & 2025 & 2026 \\
\hline JBT & $\mathbf{0}$ & 1 & 2 & 3 & 4 & 5 & 6 & 7 & 8 & 9 & 10 \\
\hline EBIT & 0,00 & $-41,17$ & $-37,50$ & $-27,14$ & $-21,71$ & $-11,53$ & $-7,72$ & 4,54 & 9,53 & 24,32 & 30,88 \\
\hline Depreciation & 0,00 & 40,40 & 40,40 & 40,40 & 40,40 & 40,40 & 40,40 & 40,40 & 40,40 & 40,40 & 40,40 \\
\hline Tax & 0,00 & 0,00 & 0,00 & 0,00 & 0,00 & 0,00 & 0,00 & 1,14 & 2,38 & 6,08 & 7,72 \\
\hline Operating Cash flow & 0,00 & $-0,77$ & 2,90 & 13,26 & 18,69 & 28,87 & 32,68 & 43,80 & 47,55 & 58,64 & 63,56 \\
\hline Investment/Reinvestment & $-500,00$ & 0,00 & 0,00 & 0,00 & 0,00 & 0,00 & 0,00 & 0,00 & 0,00 & 0,00 & 0,00 \\
\hline Salvage Value & 0,00 & 0,00 & 0,00 & 0,00 & 0,00 & 0,00 & 0,00 & 0,00 & 0,00 & 0,00 & 188,85 \\
\hline
\end{tabular}

Based on data from the table above to test the feasibility of the project financially, NPV $=-\mathrm{Rp}$ is obtained. 316,009 billion at $\mathrm{i}=13 \%$ and ten years. The IRR was $<1 \%$ and Payback Period is for more than 10 years. From these indicators, if the pattern of rental rooms / business concessions is used, this investment is not feasible (Indicator NPV $<0 \&$ IRR $<13 \%$ ). When using the Revenue Sharing pattern, the Profit / Loss Projection with the Revenue Sharing pattern is as follows:

Table 7. Projected Profit / Loss Pattern for Debt / Debt Funding with Revenue Sharing.

\begin{tabular}{|c|c|c|c|c|c|c|c|c|c|c|c|}
\hline Profit / Loss Projection & 2016 & 2017 & 2018 & 2019 & 2020 & 2021 & 2022 & 2023 & 2024 & 2025 & 2026 \\
\hline JBT & $\mathbf{0}$ & 1 & 2 & 3 & 4 & 5 & 6 & 7 & 8 & 9 & 10 \\
\hline $\begin{array}{l}\text { Total Revenue } \\
\text { Operational Cost }\end{array}$ & 0,00 & 61,77 & 71,45 & 81,81 & 93,66 & 107,24 & 122,76 & 140,50 & 160,96 & 184,30 & 211,03 \\
\hline -Employee Cost & 0,00 & 1,24 & 1,43 & 1,64 & 1,87 & 2,14 & 2,46 & 2,81 & 3,22 & 3,69 & 4,22 \\
\hline -Maitenance Cost & 0,00 & 3,09 & 3,57 & 4,09 & 4,68 & 5,36 & 6,14 & 7,03 & 8,05 & 9,22 & 10,55 \\
\hline -General Fees & 0,00 & 0,62 & 0,71 & 0,82 & 0,94 & 1,07 & 1,23 & 1,41 & 1,61 & 1,84 & 2,11 \\
\hline Operational Cost & 0,00 & 4,95 & 5,71 & 6,55 & 7,49 & 8,57 & 9,83 & 11,25 & 12,88 & 14,75 & 16,88 \\
\hline Depreciation & 0,00 & 40,40 & 40,40 & 40,40 & 40,40 & 40,40 & 40,40 & 40,40 & 40,40 & 40,40 & 40,40 \\
\hline Total Cost & 0,00 & 95,35 & 96,11 & 96,95 & 97,89 & 98,97 & 100,23 & 101,65 & 103,28 & 105,15 & 107,28 \\
\hline EBIT & 0,00 & $-33,58$ & $-24,66$ & $-15,14$ & $-4,23$ & 8,27 & 22,53 & 38,85 & 57,68 & 79,15 & 103,75 \\
\hline Interest & 0,00 & 50,00 & 45,00 & 40,00 & 35,00 & 30,00 & 25,00 & 20,00 & 15,00 & 10,00 & 5,00 \\
\hline EAI & 0,00 & $-83,58$ & $-69,66$ & $-55,14$ & $-39,23$ & $-21,73$ & $-2,47$ & 18,85 & 42,68 & 69,15 & 98,75 \\
\hline Tax & 0,00 & 0,00 & 0,00 & 0,00 & 0,00 & 0,00 & 0,00 & 9,71 & 14,42 & 19,79 & 25,94 \\
\hline EAT & 0,00 & $-83,58$ & $-69,66$ & $-55,14$ & $-39,23$ & $-21,73$ & $-2,47$ & 9,14 & 28,26 & 49,36 & 72,81 \\
\hline
\end{tabular}

And the cash flow is as follows: 
Table 8. Projection of Cash Flow Pattern of Funding Debt / Debt with Revenue Sharing.

\begin{tabular}{|c|c|c|c|c|c|c|c|c|c|c|c|}
\hline Projection of Cash Flow & 2016 & 2017 & 2018 & 2019 & 2020 & 2021 & 2022 & 2023 & 2024 & 2025 & 2026 \\
\hline JBT & $\mathbf{0}$ & 1 & 2 & 3 & 4 & 5 & 6 & 7 & 8 & 9 & 10 \\
\hline EBIT & 0,00 & $-33,58$ & $-24,66$ & $-15,14$ & $-4,23$ & 8,27 & 22,53 & 38,85 & 57,68 & 79,15 & 103,75 \\
\hline Depreciation & 0,00 & 40,40 & 40,40 & 40,40 & 40,40 & 40,40 & 40,40 & 40,40 & 40,40 & 40,40 & 40,40 \\
\hline Tax & 0,00 & 0,00 & 0,00 & 0,00 & 0,00 & 2,07 & 5,63 & 9,71 & 14,42 & 19,79 & 25,94 \\
\hline Operating Cash Flow & 0,00 & 6,82 & 15,74 & 25,26 & 36,17 & 46,60 & 57,30 & 69,54 & 83,66 & 99,76 & 118,21 \\
\hline Investment/Reinvestment & $-500,00$ & 0,00 & 0,00 & 0,00 & 0,00 & 0,00 & 0,00 & 0,00 & 0,00 & 0,00 & 0,00 \\
\hline Salvage Value & 0,00 & 0,00 & 0,00 & 0,00 & 0,00 & 0,00 & 0,00 & 0,00 & 0,00 & 0,00 & 188,85 \\
\hline
\end{tabular}

Based on data from the table above to test the feasibility of the project financially, NPV $=-\mathrm{Rp}$ is obtained. 204,439 billion at $\mathrm{I}=13 \%$ and ten years. The IRR is $5.29 \%$ and the payback period is 9-years and 8-months. From these indicators, if room rental / business concessions pattern is used, this investment is not feasible (NPV Indicator $<0 \&$ IRR $<13 \%$ ).

\section{Conclusion}

Based on the results of the analysis using capital budgeting, conclusions are obtained:

Investing in a rest area using a loan from the Bank Income with a pattern of Rent Rooms and Business Concessions financially using the Net Present Value (NPV) indicator obtained -rp. 316,009 billion at $\mathrm{I}=13 \%$ and ten years. Internal Rate of Return (IRR) $<1 \%$ with a PayBack Period for more than 10 years. From the indicators, it can be seen that financially, for JBT, when using a lease and concession pattern, this investment is not feasible to do with the feasibility indicator NPV $>0$ and IRR $>13 \%$. Likewise, with the revenuesharing pattern obtained by the Net Present Value (NPV) of Rp. 204,439 billion at I $=13 \%$ and 10 years. Internal Rate of Return (IRR) of 5.29\% with a PayBack Period for 9 years 8 months. From the indicators showing that financially for JBT, this investment is not feasible to be implemented with the feasibility indicator NPV $>0$ and IRR $>13 \%$.

Investing in the rest area by using its own capital is not feasible because it takes a long time to collect a large amount of money to be reinvested, and PT. Jasa Marga Bali Tol bears the risk of an increase in exchange rates or price increases.

Investing in the rest area using the BOT funding pattern is feasible. This event can be seen from the project NPV's value greater than 0 (zero) and the IRR greater than $13 \%$. therefore, investment in a proper rest area is continued by using the built operate Transfer (BOT) funding pattern, because now PT. JBT still has a debt burden which must be paid. The government regulations allow the use of funding patterns with BOT. Another advantages are, they do not need to pay for building assets on the land, they do not bear the risks if there is an increase for rates or price increases. They have control over live performance, service standards and maintenance of the assets built, they have the ability to terminate the contract if the performance standard is not fulfilled even though the facility can still be used continuously, they get royalties or profit parts every year from the private sector that manages the asset, and they get additional new facilities.

\section{References}

[1] Abdul, Halim. 2003. Analisis Investasi. Jakarta: Salemba Empat.

[2] Adi, Erlangga 2018. Analisis Kelayakan Investasi Pada, Rencana Pembangunan Rest Area ditinjau Dari Aspek Keuangan di PT. Jasamarga Bali Tol Denpasar Bali. Journal.

[3] Adisaputro, Gunawan, dkk. 2007. Anggaran Bisnis, Analisis, Perencanaan dan Pengendalian Laba. Yogyakarta: UPP STIM YKPN.

[4] Dede, Fathurrohman. 2008. Analisis Kelayakan Investasi untuk Rencana Perluasan Jaringan Pada PT. Telkom (Persero) Cabang Malang. Skripsi. Malang: FE-UIN.

[5] Fahmi, Irham. 2006. Analisis Investasi Dalam Perspektif Ekonomi, Dan Politik. Bandung: PT. Radika Aditama. Fahmi, Yofi. L. Hadi. 2009. Teori Portofolio, Dan Analisis Investasi. Cetakan Pertama. Bandung: Alfabeta.

[6] Husnan, Suaddan Suwarsono. 2008. Studi Kelayakan Proyek Edisi Keempat. Yogyakarta: UPP AMP YKPN.

[7] Jasa marga. Jasamarga Bali Tol (JBT). http://www.jasamarga.com/public/id/infoperusahaan/bisnis/an akperusahaan/detail.aspx?title=PT\%20Jasamarga $\% 20$ Bali $\% 20$ Tol\%20(JBT)/ (13 Maret 2018).

[8] Jumingan. 2009. Studi Kelayakan Bisnis Teori Dan Pembuatan Proposal Kelayakan. Jakarta: PT. Bumi Aksara. Kasmir dan Jakfar. 2003. Studi Kelayakan Bisnis. Jakarta: Kencana Prenada Media Group.

[9] Kasmir dan Jakfar. 2004. Studi Kelayakan Bisnis. Jakarta: Prenada Media.

[10] Kasmir dan Jakfar. 2008. Studi Kelayakan Bisnis. Edisi-2. Jakarta: Kencana Prenada Media Group.

[11] Kementrian PUPR Republik Indonesia. Tujuan dan manfaat jalan tol. http://pjt.pu.go.id/konten/jalan-tol/tujuan-danmanfaat (12 maret 2018).

[12] Kusniarti, S. 2016. Ini Rincian Pembangunan Rest Area di Tol Bali Mandara, Fasilitasnya Benar-Benar Menakjubkan. http://bali.tribunnews.com/2016/12/27/ini-rincianpembangunan-rest-area-di-tol-bali-mandara-fasilitasnyabenar-benar-menakjubkan/ (13 maret 2018).

[13] Nasution, S.H. 2011.Analisa Waktu Pelayanan Dan Profil Pemakai Jalan Tol di Gerbang Tol Balmera. http://repository.usu.ac.id/handle/123456789/ 22937/ (13 maret 2018). 
[14] Shim K. Jae dan G. Siegel G. Joel. 2001. Budgeting. Jakarta: PT. Gelora Aksara Pratama.

[15] Subagyo, Ahmad. 1997. Studi Kelayakan. Jakarta: PT. Gramedia Pustaka Umum.

[16] Suharto, Imam. 2001. Studi Kelayakan Proyek Industri. Jakarta: Erlangga.
[17] Umar, Husein. 2005. Studi Kelayakan Bisnis Edisi 3. Jakarta: PT. Gramedia Pustaka Umum.

[18] Ummah, M. B. A. 2010. Data dan Jenis Data Penelitian. http://csuryana. wordpress.com/2010/03/25/data-dan-jenisdata-penelitian/ (12 maret 2018). 